\title{
KOORDINASI KERJA PIMPINAN DINAS PERHUBUNGAN KOMUNIKASI DAN INFORMATIKA
}

\author{
Kaja \\ Fakultas Ilmu Sosial dan Ilmu Politik Universitas Kapuas \\ Gmail :kajaunka@gmail.com
}

\begin{abstract}
Abstrak : Koordinasi vertikal merupakan penyatuan kegiatan, pengarahan yang dilakukan oleh atasan terhadap kegiatan unit-unit, kesatuan-kesatuan kerja yang ada di bawah wewenang dan tanggung jawabnya. selanjut atasan mengkoordinasi semua pegawai yang ada di bawah tanggung jawabnya secara langsung. Selain itu koordinasi vertikal ini relatif mudah dilakukan, karena atasan dapat memberikan sanksi kepada pegawai yang sulit diatur. Koordinasi kerja horizontal dilakukan oleh atasan melalui pengarahan dalam kegiatan-kegiatan yang ada di kontor perhubungan komunikasi dan informatika Kabupaten Melawi. Selain itu koordinasi horizontal ini dapat menciptakan disiplin kerja antara unit yang satu dengan unit yang lain secara internal maupun eksternal pada unit-unit yang sama tugasnya. Koordinasi antar badan beserta unit-unit yang fungsinya berbeda, tetapi instansi yang satu dengan yang lain saling ketergantungan atau mempunyai kaitan setara. Pelaksanaan koordinasi horizontal ini relatif sulit dilakukan, karena tidak dapat memberikan sanksi kepada pejabat yang sulit diatur sebab kedudukannya setingkat.
\end{abstract}

Kata Kunci : Koordinasi, pimpinan

Dalam organisasi berlaku ketentuan-ketentuan dan peraturan-peraturan tertentu yang membatasi tingkah laku dan kegiatan orang-orang yang menjadi anggotanya dalam melakukan pekerjaan. Ketentuan-ketentuan atau peraturan itu sebagian bersifat tertulis yang disusun didalam bentuk undang-undang, keputusan-keputusan, peraturan, tata tertib dan lain-lainnya. Disamping itu dilingkungan suatu organisasi berlaku juga kebiasaan-kebiasaan sebagai aturan-aturan yang bersifat tidak tertulis. Kebiasaan sebagai norma hukum yang tidak tertulis itu, dipatuhi dan dilaksanakan dalam setiap langkah atau kegiatan personal, baik secara perorangan maupun kelompok untuk melakukan pekerjaan yang menjadi volume dan beban tugas suatu organisasi kerja sebagai suatu kesatuan organisasi kerja yang tidak terlepas dari ketentuan-ketentuan yang berlaku, baik berupa peraturan-peraturan tertulis maupun kebiasaankebiasaan yang tidak tertulis dilingkungannya.

Didalam Undang-Undang Nomor 43 Tahun 1999 tentang pokok-pokok kepegawaian di katakan bahwa untuk menduduki suatu jabatan dilingkungan suatu organisasi kerja yang diselenggarakan oleh pemerintah, seorang pegawai negeri harus memenuhi persyaratan atau ketentuanketentuan. Ketentuan-ketentuan itu dibedakan antara ketentuan umum dalam arti berlaku bagi semua jabatan pada semua Instansi atau lembaga Pemerintahan dan ketentuan-ketentuan khusus yang berbeda-beda antara suatu jabatan dengan jabatan yang lain sesuai dengan jenis dan sifat pekerjaan dilingkungan masing-masing. Salah satu ketentuan yang berlaku umum didalam UndangUndang Nomor 5 tahun 2014 Tentang pokok-pokok Kepegawaian menyatakan bahwa kepegawaian di Negara Indonesia menganut sistem karir dan prestasi. Bertolak dari sistem yang dianut itu berarti untuk memangku suatu jabatan disamping persyaratan masa kerja pegawai yang bersangkutan, ditentukan juga oleh prestasi kerja pegawai yang bersangkutan. Dengan demikian karir seseorang sesuai dengan golongannya akan berkelanjutan secara efektif, bila ditunjang oleh prestasi kerja yang dinilai positif dan memuaskan sesuai dengan pembagian pekerjaan yang dilaksanakan.

Jadi pembagian pekerjaan menyebabkan efektifitas secara dramatis, karena tidak seorangpun secara fisik mampu melaksanakan keseluruhan aktifitas dalam tugas-tugas yang paling rumit dan tidak seorangpun juga memiliki semua keterampilan yang diperlukan untuk melaksanakan berbagai tugas. Oleh karena itu perlu diadakan pemilahan bagian-bagian tugas dan membagi baginya kepada sejumlah orang. Pembagian pekerjaan yang dispesialisasikan seperti itu memungkinkan orang mempelajari keterampilan dan menjadi ahli pada fungsi pekerjaan tertentu. Berdasarkan pengamatan penulis dalam pra penelitian menggambarkan koordinasi kerja pimpinan di Dinas Perhubungan Komunikasi dan Informatika masih perlu ditingkatkan dan diperhatikan, hal ini dapat dilihat dari pembagian tugas dan kehadiran pegawai dalam 
melakukan pelayanan publik, jumlah pegawai masih sedikit, peralatan dan sarana kerja masih minim. Selain itu bidang pelayanan publik yang dilakukan oleh para pegawai belum dilaksanakan secara prefesional sesuai dengan bidang tugas dan ketentuan yang berlaku. Pelaksanaan koordinasi kerja pimpinan masih belum efektif dalam mengarahkan para pegawai, pembagian tugas yang kurang jelas dan menunda-nunda pekerjaan yang seharusnya pekerjaan itu mesti segera diselesaikan. Berdasarkan uraian-uraian tersebut, timbul suatu permasalahan tentang bagaimana pelaksanaan koordinasi kerja pimpinan di Dinas Perhubungan, Komunikasi dan Informatika?

Menurut Jeffrey, (1991:295) bahwa “(1) Pelaksanaan mungkin dapat dipandang sebagai sebuah proses interaktif antara suatu perangkat tujuan dan tindakan yang mampu untuk meraihnya; (2) Pelaksanaan atau penerapan program dengan demikian telah menjadi suatu jaringan yang nampak; (3) Pelaksanaan adalah kemampuan untuk membentuk hubungan yang lanjut dalam rangkaian sebab akibat yang menghubungkan tindakan dengan tujuan". Berdasarkan pendapat di atas menunjukkan bahwa pelaksanaan itu adalah melaksanakan suatu kebijakan atau program dimana akibat tersebut akan berdampak atau berpengaruh, sehingga akan membawa suatu dampak terhadap tatanan kehidupan dalam suatu organisasi. Koordinasi vertikal (Vertical Coordination) adalah kegiatan-kegiatan penyatuan, pengarahan yang dilakukan oleh atasan terhadap kegiatan unit-unit, kesatuan-kesatuan kerja yang ada di bawah wewenang dan tanggung jawabnya. Tegasnya, atasan mengkoordinasi semua aparat yang ada di bawah tanggung jawabnya secara langsung. Koordinasi vertikal ini secara relatif mudah dilakukan, karena atasan dapat memberikan sanksi kepada aparatur yang sulit diatur.

Menurut Hasibuan (2007:86-87) bahwa "koordinasi vertikal adalah kegiatan-kegiatan penyatuan, pengarahan yang dilakukan oleh atasan terhadap kegiatan unit-unti, kesatuan-kesatuan kerja yang ada di bawah wewenang dan tanggungjawabnya". Sedangkan sifat-sifat koordinasi Menurut Hasibuan (2007:87) terdapat 3 (tiga) sifat koordinasi, yaitu:" (1). Koordinasi adalah dinamis bukan statis. (2). Koordinasi menekankan pandangan menyeluruh oleh seorang koordinator (manajer) dalam rangka mencapai sasaran. (3). Koordinasi hanya meninjau suatu pekerjaan secara keseluruhan". Asas koordinasi adalah asas skala (hirarki) artinya koordinasi itu dilakukan menurut jenjang-jenjang kekuasaan dan tanggungjawab yang disesuaikan dengan jenjang-jenjang yang berbedabeda satu sama lain. Tegasnya, asas hirarki ini bahwa setiap atasan (koordinator) harus mengkoordinasikan bawahan langsungnya.
Menurut Handoko (2003:195) koordinasi (coordination) sebagai proses pengintegrasian tujuan-tujuan dan kegiatan-kegiatan pada satuansatuan yang terpisah (departemen atau bidangbidang fungsional) suatu organisasi untuk mencapai tujuan organisasi secara efisien. Menurut Handoko (2003:196) kebutuhan akan koordinasi tergantung pada sifat dan kebutuhan komunikasi dalam pelaksanaan tugas dan derajat saling ketergantungan bermacam-macam satuan pelaksananya. Hal ini juga ditegaskan oleh Handayaningrat (1985:88) bahwa koordinasi dan komunikasi adalah sesuatu hal yang tidak dapat dipisahkan. Selanjutnya, Handayaningrat juga mengatakan bahwa koordinasi dan kepemimpinan (leadership) adalah tidak bisa dipisahkan satu sama lain, karena satu sama lain saling mempengaruhi.

Terdapat 3 (tiga) macam saling ketergantungan di antara satuan-satuan organisasi seperti diungkapkan oleh James (dalam Handoko, 2003:196), yaitu: 1. Saling ketergantungan yang menyatu (pooled interdependence), bila satuansatuan organisasi tidak saling tergantung satu dengan yang lain dalam melaksanakan kegiatan harian tetapi tergantung pada pelaksanaan kerja setiap satuan yang memuaskan untuk suatu hasil akhir. 2. Saling ketergantungan yang berurutan (sequential interdependece), di mana suatu satuan organisasi harus melakukan pekerjaannya terlebih dulu sebelum satuan yang lain dapat bekerja. 3 . Saling ketergantungan timbal balik (reciprocal interdependence), merupakan hubungan memberi dan menerima antar satuan organisasi. Selanjutnya Handoko (2003:196) juga menyebutkan bahwa derajat koordinasi yang tinggi sangat bermanfaat untuk pekerjaan yang tidak rutin dan tidak dapat diperkirakan, faktor-faktor lingkungan selalu berubah-ubah serta saling ketergantungan adalah tinggi. Koordinasi juga sangat dibutuhkan bagi organisasi-organisasi yang menetapkan tujuan yang tinggi.

Koordinasi horizontal ini relatif sulit dilakukan, karena koordinator tidak dapat memberikan sanksi kepada pejabat yang sulit diatur sebab kedudukannya setingkat. Koordinasi Pimpinan merupakan penyesuaian diri dari bagian-bagian satu sama lain, dan gerakan serta pengerjaan bagian-bagian pada saat yang tepat sehingga masing-masing dapat memberikan sumbangan yang maksimum pada hasil secara keseluruhan. Dalam kelangsungan, keharmonisan mencapai tujuan, yang dapat dicapai melalui kepemimpinan, organisasi, dan administrasi. Penyusunan usaha-usaha kelompok di dalam suatu kelangsungan dan keteraturan sikap sehingga menciptakan kesatuan tindakan dalam mengusahakan tercapainya tujuan bersama. Koordinasi "pengaturan usaha sekelompok orang 
secara teratur untuk menciptakan kesatuan tindakan dalam mengusahakan tercapainya suatu tujuan bersama".

Koordinasi tidak terdapat unsur kerjasama secara suka rela, tetapi bersifat kewajiban (compulsory). Syarat-syarat koordinasi Menurut Hasibuan (2007:88) terdapat 4 (empat) syarat koordinasi, yaitu: 1. Sense of cooperation (perasaan untuk bekerjasama), ini harus dilihat dari sudut bagian per bagian bidang pekerjaan, bukan orang per orang. 2. Rivalry, dalam perusahaan-perusahaan besar sering diadakan persaingan antara bagian-bagian, agar bagian-bagian ini berlomba-lomba untuk mencapai kemajuan 3. Team spirit, artinya satu sama lain pada setiap bagian harus saling menghargai. 4. Esprit de corps, artinya bagianbagian yang diikutsertakan atau dihargai, umumnya akan menambah kegiatan yang bersemangat. Koordinasi adalah proses di mana pimpinan mengembangkan pola yang teratur dari usaha kelompok di antara para bawahannya dan kepastian kesatuan tindakan dalam usaha mencapai tujuan bersama. Koordinasi harus ada untuk menyempurnakan banyak usaha agar supaya pencapaian tujuan efektif. Koordinasi memungkinkan kesatuan usaha mental dan pisik dalam bermacam-macam sikap karena menciptakan kelebihan usaha yang dikoordinasikan pada sejumlah usaha individu dari para peserta". Berdasarkan pendapat tentang koordinasi seperti telah dikemukakan oleh para ahli tersebut di atas dapat disimpulkan sebagai berikut : (1) Koordinasi berintisarikan kesatuan tindakan atau kesatuan usaha; (2) Koordinasi berintisarikan penyesuaian antara bagian; (3) Koordinasi berintisarikan keseimbangan antarsatuan; (4) Koordinasi berintisarikan keselarasan; (5) Koordinasi berintisarikan sinkronisasi Dari berbagai intisari tentang koordinasi seperti tersebut di atas sebenarnya dapat dipakai satu istilah yaitu keselarasan. Baik kesatuan tindakan, kesatuan usaha, penyesuaian antar bagian, keseimbangan antarbagian maupun sinkronisasi semuanya bersasaran keselarasan. Atas dasar itu dapatlah kiranya asas koordinasi diartikan sebagai berikut, yaitu di dalam organisasi harus ada keselarasan aktivitas antar satuan organisasi atau keselarasan tugas antar pejabat.

Kepemimpinan dibutuhkan oleh manusia karena adanya suatu keterbatasan dan kelebihankelebihan tertentu pada manusia. Maksudnya di satu pihak manusia terbatas kemampuannya untuk memimpin, sementara dilain pihak ada orang yang memiliki kelebihan kemampuan untuk memimpin. Dari keadaan inilah maka timbul akan kebutuhan akan seorang pemimpin. Pemimpin merupakan salah satu intisari manajemen, sumber daya pokok dan titik sentral dari setiap aktivitas yang terjadi dalam suatu organisasi. Kreativitas seorang pemimpin dalam menjalankan wewenangnya, sangat menentukan keberhasilan organisasi yang hendak di capai. Kepemimpinan merupakan faktor yang sangat penting dalam mempengaruhi prestasi organisasi, karena kepemimpinan merupakan aktivitas utama di mana, melalui kegiatan kepemimpinan tujuan organisasi dapat di capai.

Menurut Louis A. Allen (dalam Nawawi, 2001:225) bahwa setiap organisasi kerja termasuk juga lembaga-lembaga pemerintah, setiap pimpinannya berkewajiban menggerakkan dan mengarahkan semua personal atau pegawai agar mewujudkan volume atau beban kerja masingmasing. Sejalan dengan pendapat itu Nawawi $\mathrm{H}$. (2001:225) mengatakan sebagai berikut: Kepemimpinan adalah tindakan atau perbuatan diantara perseorangan dan kelompok yang menyebabkan baik orang seorang maupun kelompok bergerak kearah tujuan tertentu. Kepemimpinan tampak dalam proses dimana seseorang mengarahkan, membimbing, mempengaruhi, dan atau mengawasi pikiranpikiran, perasaan atau tingkah laku orang lain.

Dari pengertian tersebut di atas, bahwa organisasi formal, kepemimpinan merupakan masalah sentral dalam kepengurusan organisasi. Kepemimpinan dapat dilihat sebagai proses kekuatan dibalik sukses suatu organisasi. Toha (1993:1) mengatakan suatu organisasi akan berhasil atau gagal ditentukan oleh kepemimpinan itu sendiri, karena begitu pentingnya peranan kepemimpinan dalam suatu organisasi mencapai suatu tujuan organisasi yang telah ditetapkan. Menurut Siagian (1983:24) kepemimpinan sebagai kemampuan dan keterampilan seseorang yang menduduki jabatan sebagai pemimpin satuan kerja untuk mempengaruhi perilaku orang lain terutama bawahannya, untuk berpikir dan bertindak sedemikian rupa sehingga melalui perilaku yang positif ia memberikan sumbangsih nyata dalam pencapaian tujuan organisasi. Berdasarkan pengertian di atas menggambarkan bahwa kepemimpinan adalah merupakan kegiatan pemimpin untuk mempengaruhi orang lain atau bawahannya dalam berbagai situasi dan kondisi agar bersedia dengan ikhlas baik secara bersamasama atau secara perorangan, melaksanakan tanggung jawabnya terhadap tugas-tugas yang dibebankan kepadanya dalam rangka pencapaian tujuan yang diinginkan. Dengan demikian kepemimpinan merupakan sebuah proses memberi arti (pengarahan yang berarti) terhadap usaha kolektif, dan yang mengakibatkan kesediaan untuk melakukan usaha yang diinginkan untuk mecapai sasaran.

Teori kepemimpinan menurut Gitosudarmo dan Sudita tersebut, merupakan teori yang 
dikembangkan dari tahun 1940-an. Teori mencakup sifat atau karakteristik individu pemimpin, perilaku pemimpin dalam memimpin bawahannya, kemudian situasi yang dihadapi oleh pemimpin serta tugas seorang pemimpin sebagai pengolah informasi. Menurut Toha (2001:180) bahwa "motivasi Perilaku manusia itu hakikatnya adalah berorientasi pada tujuan dengan kata lain bahwa perilaku seseorang itu pada umumnya dirangsang oleh keinginan untuk mencapai beberapa tujuan. Satuan dasar dari setiap perilaku adalah kegiatan. Sehingga dengan demikian semua perilaku itu adalah serangkaian aktivitasaktivitas atau kegiatan-kegiatan". Pengertian motivasi yang disebutkan oleh Hasibuan maupun Winardi serta pendapat Thoha tersebut menjelaskan bahwa setiap tindakan atau aktifitas yang dilakukan oleh manusia itu senantiasa memiliki tujuan tertentu. Manusia mengerjakan sesuatu karena ada sesuatu hal yang mendorongnya.

Dalam memberikan motivasi seorang pimpinan harus memikirkan mengenai perkiraanperkiraan tentang kebutuhan atau hal-hal yang dapat merangsang gairah kerja bawahannya. Terdapat beberapa pendapat para ahli mengenai motivasi, beberapa pendapat tersebut diuraikan sebagai bahwa Menurut Winardi (2001:6) pengertian motivasi sebagai berikut: Motivasi adalah suatu kekuatan potensial yang ada dalam diri seorang manusia, yang dapat dikembangkannya sendiri, atau dikembangkan oleh sejumlah kekuatan luar yang pada intinya berkisar sekitar imbalan moneter dan imbalan non-moneter, yang dapat mempengaruhi hasil kinerjanya secara positif atau secara negatif, hal mana tergantung pada situasi dan kondisi yang dihadapi orang yang bersangkutan. Banyak teori atau pendapat para ahli tentang motivasi. Empat teori diantaranya; (1) Teori tingkat kebutuhan Abraham Maslow, (2) Teori dua faktor Frederick Fferzberg, (3) Teori motivasi prestasi David mcclelland, (4) Teori X dan Y yang dikembangkan oleh Mcgregor. Satu dari banyak teori motivasi yang secara luas diketahui adalah teori tingkat kebutuhan (hierarchy of needs) yang dikembangkan oleh psikolog bernama Abraham Maslow pada tahun 1935. Teori ini menekankan bahwa manusia terdorong untuk melakukan usaha untuk memuaskan lima kebutuhan dasar yang belum terpuaskan yang melekat pada diri manusia itu sendiri. Mangkunegara (2001:101) mengemukakan terdapat beberapa teknik memotivasi yaitu teknik pemenuhan kebutuhan pegawai dan teknik komunikasi persuasif. Kedua teknik tersebut dijelaskan sebagai berikut :

Pemenuhan kebutuhan pegawai merupakan fundamental perilaku kerja. Kita tidak mungkin dapat memotivasi kerja pegawai tanpa memperhatikan apa yang dibutuhkan. Abraham Maslow dalam Prabu Mangkunegara (2001:101) mengemukakan hierarki kebutuhan pegawai sebagai berikut. 1. Kebutuhan fisiologis, yaitu kebutuhan makan, minum, perlindungan fisik, bernapas, dan seksual. Kebutuhan ini merupakan kebutuhan yang paling mendasar. Dalam hubungan dengan kebutuhan ini pemimpin perlu memberikan gaji yang layak kepada pegawai. 2. Kebutuhan rasa aman, yaitu kebutuhan perlindungan dari ancaman, bahaya, dan lingkungan kerja. Dalam hubungan dengan kebutuhan ini pemimpin perlu memberikan tunjangan kesehatan, asuransi kecelakaan, perumahan, dan dana pensiun. 3. Kebutuhan sosial atau rasa memiliki, yaitu kebutuhan untuk diterima dalam kelompok unit kerja, berafiliasi, berinteraksi, serta rasa dicintai dan mencintai. Dalam hubungan dengan kebutuhan ini, pemimpin perlu menerima eksistensi atau keberadaan pegawai sebagai anggota kelompok kerja, melakukan interaksi kerja yang baik, dan hubungan kerja yang harmonis. 4 . Kebutuhan harga diri, yaitu kebutuhan untuk dihormati, dihargai oleh orang lain. Dalam hubungan dengan kebutuhan ini, pemimpin tidak boleh sewenang-wenang memperlakukan pegawai karena mereka perlu dihormati, diberi penghargaan terhadap prestasi kerjanya. 5. Kebutuhan aktualisasi diri, yaitu kebutuhan untuk mengembangkan diri dan potensi, mengemukakan ide-ide, memberikan penilaian, kritik, dan berprestasi.

Kebutuhan inilah yang mendorong seorang seniman mengungkapkan keahliannya di atas kanvas, kebutuhan yang memotivasi seseorang untuk bekerja pada siang hari dan kemudian mengikuti kuliah sore untuk mendapatkan gelar kesarjanaan. Dalam hubungannya dengan kebutuhan ini di dalam perusahaan atau organisasi, pemimpin perlu memberi kesempatan kepada pegawai bawahan agar mereka dapat mengaktualisasikan diri secara baik dan wajar di perusahaan. Teknik komunikasi persuasif merupakan salah satu teknik memotivasi kerja pegawai yang dilakukan dengan cara mempengaruhi pegawai secara ekstralogis. Prabu Mangkunegara (2001:102) merumuskan teknik ini adalah : (1) Attention (Perhatian); (2) Interest (Minat); (3) Desire (Hasrat); (4) Decision (Keputusan); (5) Action (Aksi/Tindakan); (6) Satisfaction (Kepuasan). Penggunaannya, pertama kali pemimpin harus memberikan perhatian kepada pegawai tentang pentingnya tujuan dari suatu pekerjaan agar timbul minat pegawai terhadap pelaksanaan kerja, jika telah timbul minatnya maka hasratnya menjadi kuat untuk mengambil keputusan dan melakukan tindakan kerja dalam mencapai tujuan yang diharapkan oleh pemimpin.

Oleh sebab itu, organisasi harus dilihat dari dua pengertian pertama menandakan suatu lembaga atau kolompok fungsional. Pengertian kedua berkenaan proses pengorganisasian menyangkut 
bagaimana kegiatan organisasi dialokasikan serta pembagian pekerjaan di antara anggotanya agar tujuan organisasi dapat tercapai dengan efisien. Sejalan dengan pendapat tersebut Manullang (2005:60) mendefinisikan organisasi sebagai berikut : 1. Organisasi dalam arti badan adalah sekelompok orang yang bekerja sama untuk mencapai suatu tujuan tertentu. 2. Organisasi dalam arti bagan atau struktur adalah gamabaran secara skematis tentang hubungan-hubungan, kerjasama dari orang-orang yang terdapat dalam rangka usaha mencapai suatu tujuan. Menunurut Gibson (1997:5) bahwa "Organisasi adalah kesatuan yang memungkinkan anggota mencapai tujuan yang tidak dapat dicapai melalui tindakan individu secara terpisah". Pada dasarnya organisasi merupakan suatu kerjasama dalam suatu tim yang diartikan tidak dapat terpisah dengan kegiatan lainnya. Proses kerjasam tersebut dapat digabungkan dalam suatu pekerjaan yang akan menjadi suatu kelompok. Menurut Sheldon (dalam Sutarto,1993:1) bahwa "Organisasi adalah proses penggabungan pekerjaan pada individu atau kelompok-kelompok harus melakukan dengan bakat yang diperlukan untuk melakukan tugas-tugas sedemikian rupa memberikan saluran terbaik untuk pemakaian yang efisien, sistematis, positif, dan terkoordinasikan dari usaha tersedia". Pelaksanaan pekerjaan atau kegiatan dalam organisasi sudah barang tentu yang paling penting dalam fungsi manajemen karena merupakan pengupayaan berbagai jenis tindakan itu sendiri, agar semua anggota kelompok mulai dari tingkat teratas sampai terbawah berusaha mencapai sasaran organisasi sesuai rencana yang telah ditetapkan semula dengan cara terbaik dan benar.

Berdasarkan pendapat tersebut bahwa faktor yang mempengaruhi proses koordinasi antara lain ketersediaan susunan organisasi yang efisien dan efektif, adanya fasilitas-fasilitas fisik yang baik, adanya fasilitas pelayanan dan komunikasi, adanya hubungan kerja yang memuaskan, analisis dan metode-metode yang prosedural dan yang mengawasi aktivitas-aktivitas kantor. Tujuan organisasi pemerintah dijabarkan dalam tugas dan fungsi yang secara operasional dijalankan oleh sekolah yang bersangkutan. Menurut Gouzali (2000:201) "organisasi yang baik harus berupaya menciptakan peraturan tata tertib yang akan dijadikan rambu-rambu yang harus dipatuhi oleh seluruh pegawi dalam organisasi”. Berdasarkan pendapat tersebut di atas dapat disimpulkan bahwa faktor-faktor yang mempengaruhi proses koordinasi kerja pimpinan lain besar kecilnya pemberian kompensasi, ada tidaknya keteladanan pimpinan, ada tidaknya aturan pasti yang dapat dijadikan pegangan, keberanian pimpinan dalam mengambil tindakan, ada tidaknya pengawasan pimpinan, ada tidaknya perhatian kepada karyawan serta diciptakan kebiasaan-kebiasaan yang mendukung tegaknya disiplin. Struktur organisasi akan mempengaruhi pembagian tugas. Pembagian tugas akan mempengaruhi kewenangan dan tanggung jawab bagi tiap pegawai. Pengaturan yang terlalu ketat akan menimbulkan birokrasi yang akhirnya akan mempengaruhi efisiensi, sedangkan pengaturan yang terlalu longgar akan mengaburkan batas-batas kewenangan. Demikian juga dengan penerapan peraturan organisasi yang harus dilaksanakan dengan adil. Budaya organisasi: kebiasaan yang berlaku dalam organisasi yang dijadikan acuan bagi para anggota organisasi. Seringkali budaya organisasi suatu perusahaan dianggap unik oleh organisasi lain. Dalam hal ini maka perlu dilakukan pengaturan yang luwes dengan tetap memperhatikan produktivitas kerja bagi aparatur pemerintahan tersebut.

Struktur merupakan petunjuk tentang tugas dan tanggung jawab masing-masing wali kelas, dengan adanya struktur atau pembagian tugas yang jelas maka dapat dikoordinasikan baik secara vertikal maupun horizontal sehingga pelaksanaan belajar mengajar dapat dikoordinasikan secara efektif dan efisien. Organisasi yang mampu beradaptasi dengan tuntutan permintaan dan mengisi peluang yang ada, akan mampu untuk hidup terus dan berkembang. Struktur organisasi berkaitan dengan hubungan yang bersifat relatif tetap dalam organisasi, bagaimana pekerjaanpekerjaan dalam organisasi dirancang, bagaimana pekerjaan itu diatur dalam bagan organisasi, struktur organisasi berpengaruh besar terhadap perilaku individu atau orang-orang dalam organisasi serta efektivitas dalam organisasi tersebut.

Dengan demikian, organisasi selain membawa pengaruh pada perilaku individu dan kelompok dalam organisasi juga berpengaruh dan dipengaruhi oleh lingkungan organisasi itu sendiri, dalam mencapai tujuan organisasi. Pelaksanaan kegiatan belajar mengajar sudah barang tentu yang paling penting dalam fungsi sekolah karena merupakan upaya berbagai jenis tindakan itu sendiri, agar semua anggota kelompok mulai dari tingkat teratas sampai terbawah berusaha mencapai sasaran organisasi sesuai rencana yang telah ditetapkan semula dengan cara terbaik dan benar.

\section{METODE PENELITIAN}

Jenis Penelitian ini menggunakan metode deskriptif yaitu suatu penelitian yang menekankan pada prosedur pemecahan masalah yang diselidiki dengan melukiskan keadaan subjek penelitian. pada saat sekarang berdasarkan fakta yang nampak atau sebagaimana adanya. Menurut Suryabrata (2000:18) bahawa penelitian deskriftif adalah" untuk membuat pencandraan sistematis, faktual dan akurat mengenai fakta- fakta dan sifat-sifat populasi atau daerah tertentu". Sedangkan Nawawi 
(2001:63) penelitian deskriptif diartikan sebagai prosedur pemecahan masalah yang diselidiki dengan menggambarkan/melukiskan keadaan subjek/objek penelitian ( seseorang, keluarga, masyarakat dan lain-lain) pada saat sekarang berdasarkan faktafakta yang tampak atau sebagaimana adanya". Menurut Faisal (1990:109) bahwa subjek penelitian adalah menunjuk pada orang/individu atau kelompok yang dijadikan inti atau satuan (khusus) yang diteliti". Maka akan digunakan subjek penelitian. Subjek penelitian ini adalah sebagai berikut : Kepala Dinas Perhubungan Kabupaten Melawi, Kepala Seksi Komunikasi Dinas Perhubungan Kabupaten melawi, Pegawai Dinas Perhubungan Kabupaten Melawi

Alasan dalam pemilihan subjek penelitian adalah yang bersangkutan mengerti, mengetahui dan memahami masalah koordinasi kerja pimpinan, sehingga memudahkan untuk mendapatkan data dan informasi yang sesuai dengan tujuan penelitian ini. Teknik pengumpulan data yang digunakan dalam pelitian adalah : Wawancara, Observasi, Studi Dokumentasi. Alat pengumpulan data yang di maksud dalam penelitian ini adalah : Pedoman Wawancara, Pedoman Observasi. Setelah keseluruhan data yang diperlukan terkumpul, maka pengolahan data dalam penelitian ini menggunakan teknik analisis kualitatif. Teknik analisis kualitatif yaitu setelah seluruh data terkumpul baik data primer maupun data sekunder, maka data tersebut dituangkan dalam pernyataan-pernyataan, kalimatkalimat atau ungkapan-ungkapan berupa naratif, yang pada akhirnya dianalisis sesuai dengan tujuan penelitian. Selanjutnya akan ditarik suatu kesimpulan sebagai akhir dari analisis data.

Teknik analisis data dalam penelitian ini menggunakan deskrifsi data yaitu data mentah yang telah terkumpul kemudian dideskrifsikan dan digeneralisasikan serta ditarik suatu kesimpulan secara kualitatif. Menurut Chris (dalam Singaribun,1989:263) analisis data adalah "penyerdehanaan data kedalam bentuk yang lebih mudah dibaca dan diterprestasikan. Fungsi dari analisis data adalah memperlakukan data empiris kedalam suatu bentuk yang dapat diinterprestasikan dan dapat pula memberikan kejelasan sebagai jawaban atas pemecahan masalah". Lokasi penelitian ini di Dinas Perhubungan Komunikasi dan Informatika Kabupaten Melawi. Alasan memilih lokasi tersebut adalah sebagi berikut : a. Secara Metodologis, karena Dinas Perhubungan, Komunikasi dan Informatika Kabupaten Melawi dapat memeberikan informasi dan dapat menyajikan data yang diperlukan oleh peneliti untuk menjelaskan fenomena kejadian yang sebenarnya dari permasalahan dalam penelitian ini. b. Secara Praktis, penelitian ini dapat memberikan sumbangan pemikiran kepada istansi terkait tentang koordinasi kerja pimpinan yang masih terindikasi kurang maksimal di lakukan di dinas perhubungan komunikasi dan informatika ini.

\section{HASIL PENELITIAN DAN PEMBAHASAN}

Sehubungan dengan ditetapkanya Peraturan Pemerintah Nomor 41 Tahun 2007 Tentang Organisasi Perangkat Daerah, maka berpedoman pada atauran tersebut dilakuakan penataan ulang terhadap Susunan Organisasi Perangkat Daerah Kabupaten Melawi sehingga ditetapkan Peraturan Daerah Melawi Nomor 2 Tahun 2008 Tentang Susunan Organisasi Perangkat Daerah Pemerintah Kabupaten Sintang dan dijabarkan dalam Peratuaran Bupati Sintang Nomor 36 Tahun 2008 Tentang Susunan Organisasi Dan Tata Kerja Dinas perhubungan Kabupaten Melawi. Koordinasi vertikal merupakan salah bentuk kegiatan penyatuan, pengarahan yang dilakukan oleh atasan terhadap kegiatan dimasing-masing bagian dinas perhubungan Kabupaten Melawi. Selain iti adanya kesatuan kerja yang ada di bawah wewenang dan tanggung jawabnya pimpinan bain secara langsung maupun tidak langsung. Menurut hemat kami bahwa koordinasi kerja yang ada di dinas ini telah diarahkan sesuai dengan tugas pokok dan fungsi seluruh pegawai yang ada di bawah tanggung jawab pimpinan secara langsung. Selain itu koordinasi kerja vertikal ini secara relatif mudah dilakukan, karena atasan dapat memberikan sanksi kepada aparatur yang sulit diatur.

Komunikasi Dinas Perhubungan komunikasi dan Informatika dalam pelaksanaan koordinasi telah dilakukan pimpinan secara berkelanjutan, baik melalui intruksi dan pengarahan antara bagian yang ada di kantor ini. Selain itu koordinasi kerja merupakan suatu usaha yang sinkron dan teratur untuk menyediakan jumlah dan waktu yang tepat, dan mengarahkan pelaksanaan untuk menghasilkan suatu tindakan yang seragam dan harmonis pada sasaran yang telah ditentukan. Koordinasi kerja pimpinan menggerakkan tim dengan memberikan kegiatan pekerjaan yang cocok dan masing-masing menjaga agar kegiatan organisasi dilaksanakan dengan keselarasan yang semestinya di antara para pegawai itu sendiri. Pelaksanaan koordinasi telah dilakukan pimpinan secara berkelanjutan, baik melalui intruksi dan pengarahan antara bagian yang ada di kantor ini. Selain itu koordinasi kerja merupakan suatu usaha yang sinkron dan teratur untuk menyediakan jumlah dan waktu yang tepat, dan mengarahkan pelaksanaan untuk menghasilkan suatu tindakan yang seragam dan harmonis pada sasaran yang telah ditentukan. 
Koordinasi vertikal dilakukan pimpinan merupakan salah satu kegiatan-kegiatan penyatuan, pengarahan yang dilakukan oleh atasan terhadap kegiatan unit-unti, kesatuan-kesatuan kerja yang ada di bawah wewenang dan tanggungjawabnya. Sedangkan sifat-sifat koordinasi Koordinasi adalah dinamis bukan statis. Koordinasi menekankan pandangan menyeluruh oleh seorang koordinator dalam rangka mencapai sasaran. Koordinasi hanya meninjau suatu pekerjaan secara keseluruhan. Asas koordinasi adalah asas skala artinya koordinasi itu dilakukan menurut jenjang-jenjang kekuasaan dan tanggungjawab yang disesuaikan dengan jenjangjenjang yang berbeda-beda satu sama lain.

Koordinasi horizontal telah dilakukan mengkoordinasikan tindakan-tindakan atau kegiatan-kegiatan kantor, pengarahan yang dilakukan terhadap kegiatan-kegiatan dalam tingkat organisasi yang setingkat. Koordinasi horizontal ini suatu koordinasi dalam rangka mengarahkan, menyatukan tindakan-tindakan, mewujudkan, dan menciptakan disiplin antara unit yang satu dengan unit yang lain secara intern maupun ekstern pada unit-unit yang sama tugasnya. Sedangkan koordinasi antar badan beserta unit-unit yang fungsinya berbeda, tetapi instansi yang satu dengan yang lain saling bergantung atau mempunyai kaitan secara intern atau ekstern yang levelnya setara. Koordinasi horizontal ini relatif sulit dilakukan, karena koordinator tidak dapat memberikan sanksi kepada pejabat yang sulit diatur sebab kedudukannya setingkat.

Komunikasi Dinas Perhubungan komunikasi dan Informatika di ketahui bahwa Koordinasi Pimpinan merupakan penyesuaian diri dari bagian-bagian satu sama lain, dan gerakan serta pengerjaan bagian-bagian pada saat yang tepat sehingga masing-masing dapat memberikan sumbangan yang maksimum pada hasil secara keseluruhan. Dalam kelangsungan, keharmonisan mencapai tujuan, yang dapat dicapai melalui kepemimpinan, organisasi, dan administrasi. Penyusunan usaha-usaha kelompok di dalam suatu kelangsungan dan keteraturan sikap sehingga menciptakan kesatuan tindakan dalam mengusahakan tercapainya tujuan bersama. Koordinasi pengaturan usaha sekelompok orang secara teratur untuk menciptakan kesatuan tindakan dalam mengusahakan tercapainya suatu tujuan bersama.

Koordinasi Pimpinan merupakan penyesuaian diri dari bagian-bagian satu sama lain, dan gerakan serta pengerjaan bagian-bagian pada saat yang tepat sehingga masing-masing dapat memberikan sumbangan yang maksimum pada hasil secara keseluruhan. Dalam kelangsungan, keharmonisan mencapai tujuan, yang dapat dicapai melalui kepemimpinan, organisasi, dan administrasi. Penyusunan usahausaha kelompok di dalam suatu kelangsungan dan keteraturan sikap sehingga menciptakan kesatuan tindakan dalam mengusahakan tercapainya tujuan bersama. Koordinasi merupakan proses di mana pimpinan mengembangkan pola yang teratur dari usaha kelompok di antara para bawahannya dan kepastian kesatuan tindakan dalam usaha mencapai tujuan bersama. Koordinasi harus ada untuk menyempurnakan banyak usaha agar supaya pencapaian tujuan efektif. Koordinasi memungkinkan kesatuan usaha mental dan pisik dalam bermacam-macam sikap karena menciptakan kelebihan usaha yang dikoordinasikan pada sejumlah individu dari para pegawai.

Dengan demikian seorang Pemimpin memiliki peranan yang dominan dalam sebuah organisasi. Peranan yang dominan tersebut dapat mempengaruhi moral kepuasan kerja keamanan, kualitas kehidupan kerja dan terutama tingkat prestasi suatu organisasi. Sebagaimana bahwa pemimpin juga memainkan peranan yang baik dalam membantu kelompok organisasi, atau masyarakat untuk mencapai tujuan. Kepemimpinan merupakan bagian penting dari manejemen, tetapi tidak sama dengan manajemen. Kepemimpinan merupakan kemampuan yang dipunyai seseorang untuk mempengaruhi orang lain agar bekerja mencapai tujuan dan sasaran. Manajemen mencakup kepemimpinan tetapi juga mencakup fungsifungsi lainnya seperti perencanaan, penorganisasian, pengawasan dan evaluasi. Kepemimpinan dalam pengertian umum menunjukkan suatu proses kegiatan dalam hal memimpin, membimbing, mengontrol perilaku, perasaan serta tingkah laku terhadap orang lain yang ada dibawah pengawasannya. Disinilah peranan kepemimpinan berpengaruh besar dalam pembentukan perilaku bawahan. Kepemimpinan merupakan kemampuan seseorang untuk mempengaruhi orang lain agar mencapai tujuan dan sasaran. Kelangsungan hidup suatu negara bahkan sampai pada suatu organisasi terkecilpun baik organisasi formal seperti kelurahan maupun non formal, maju mundurnya sangat dipengaruhi oleh para pemimpin-pemimpinnya. Kepemimpinan dapat dipandang sebagai pangkal penyebab daripada kegiatan-kegiatan, proses atau kesediaan untuk merubah pandangan atau sikap dari pada kelompok orang, baik dalam hubungan formal maupun informil.

Kemampuan yang harus dimiliki pemimpin adalah kemandirian, berhasrat memajukan diri sendiri, rasa ingin tahu dan cepat tertarik pada manusia dan benda-benda; multi terampil atau 
memiliki keterampilan beraneka ragam; memiliki rasa humor, anthusiasme tinggi, suka berkawan; perfeksionisme, selalu ingin mendapatkan yang sempurna; mudah menyesuaikan diri, adaptasinya tinggi; sabar, namun tidak mandek atau berhenti; waspada, peka, jujur, optimis, berani, gigih, ulet, realistis; komunikatif, serta pandai berbicara dan berpidato; berjiwa wiraswasta; sehat jasmaninya, dinamis, sanggup dan suka menerima tugas yang berat serta mengambil resiko yang berani;tajam firasatnya, tajam dan adil pertimbangannya; berpengetahuan luas,d an haus akan ilmu pengetahuan; memiliki motivasi tinggi dan menyadari target atau tujuan hidupnya yang ingi dicapai. Kepemimpinan dibutuhkan oleh manusia karena adanya suatu keterbatasan dan kelebihankelebihan tertentu pada manusia. Maksudnya di satu pihak manusia terbatas kemampuannya untuk memimpin, sementara dilain pihak ada orang yang memiliki kelebihan kemampuan untuk memimpin. Dari keadaan inilah maka timbul akan kebutuhan akan seorang pemimpin. Pemimpin merupakan salah satu intisari manajemen, sumber daya pokok dan titik sentral dari setiap aktivitas yang terjadi dalam suatu organisasi. Kreativitas seorang pemimpin dalam menjalankan wewenangnya, sangat menentukan keberhasilan organisasi yang hendak di capai.

Oleh karena itu motivasi yang diberikan pemimpin berupa pandangan dan dorongan dalam bentuk hadiah kepada pegawai yang berprestasi baik, dengan adanya perhatian dan dorongan, maka semangat kerja bawahan akan meningkat, karena manusia pada umumnya senang menerima yang baik-baik saja. Kemudian ada motivasi negatif yakni pimpinan memotivasi bawahan dengan memberikan hukuman kepada mereka yang pekerjaannya kurang baik. Setiap orang termotivasi atau terdorong untuk berperilaku dalam cara tertentu yang dirasakan mengarah kepada perolehan ganjaran. Tetapi, memotivasi seseorang lebih mudah diucapkan daripada dilaksanakan, karena tiap orang memiliki kebutuhan yang berbedabeda. Oleh karena itu, setelah membicarakan mekanisme atau proses motivasi, maka perbincangan akan mengarah pada persoalan halhal yang dibutuhkan dan diinginkan orang-orang. Ada beberapa teknik memotivasi kerja pegawai yaitu teknik pemenuhan kebutuhan pegawai dan teknik komunikasi persuasif.

Motivasi tersebut pada dasarnya muncul apabila terjadi dua hal yaitu, apabila nilai hasil tertentu sangat tinggi bagi orang yang menerimanya, dan apabila orang itu merasa bahwa ia memiliki kesempatan yang cukup baik untuk menyelesaikan tugas dan memperoleh hasilnya, memotivasi seseorang lebih mudah diucapkan daripada dilaksanakan, karena tiap orang memiliki kebutuhan. Kita tidak mungkin dapat memotivasi kerja pegawai tanpa memperhatikan apa yang dibutuhkan. Kebutuhan fisiologis, yaitu kebutuhan makan, minum, perlindungan fisik, bernapas, dan seksual. Kebutuhan ini merupakan kebutuhan yang paling mendasar. Dalam hubungan dengan kebutuhan ini pemimpin perlu memberikan gaji yang layak kepada pegawai. Kebutuhan rasa aman, yaitu kebutuhan perlindungan dari ancaman, bahaya, dan lingkungan kerja.

Seorang pemimpin selalu melayani masyarakat dan dapat memadukan kebutuhan dari masyarakat dengan kebutuhan organisasi dan kebutuhan masyarakat secara keseluruhannya. Kepala Dinas dapat memberikan arahan dan kapada pegawa sehingga para pegawai merasakan pelayanan yang baik. Kepemimpinan penting dalam kehidupan bersama dan kepemimpinan itu hanya melekat pada orang dan kepemimpinan itu harus mengena kepada orang yang dipimpinnya. Hal ini berarti harus diakui secara timbal balik misalnya sasaran yang dipimpin harus mengakui bahwa orang tersebut adalah pemimpinnya. Dalam hubungan dengan kebutuhan ini pemimpin perlu memberikan tunjangan kesehatan, asuransi kecelakaan, perumahan, dan dana pensiun. Kebutuhan sosial atau rasa memiliki, yaitu kebutuhan untuk diterima dalam kelompok unit kerja, berafiliasi, berinteraksi, serta rasa dicintai dan mencintai. Dalam hubungan dengan kebutuhan ini, pemimpin perlu menerima eksistensi atau keberadaan pegawai sebagai anggota kelompok kerja, melakukan interaksi kerja yang baik, dan hubungan kerja yang harmonis. Kebutuhan harga diri, yaitu kebutuhan untuk dihormati, dihargai oleh orang lain.

Jenis motivasi yang diberikan pemimpin adalah motivasi positif yang diberikan pimpinan kepada bawahan dengan memberikan hadiah kepada mereka yang berpartisipasi baik, dengan motivasi positif ini semangat kerja bawahan akan meningkat, karena manusia pada umumnya senang menerima yang baik-baik saja. Kemudian ada motivasi negatif yakni pimpinan memotivasi bawahan dengan memberikan hukuman kepada mereka yang pekerjaannya kurang baik. Dengan motivasi negatif ini semangat kerja bawahan dalam waktu pendek akan meningkat, karena mereka takut dihukum; tetapi untuk jangka waktu panjang akan berakibat kurang baik. Jenis-jenis motivasi yang dikemukakan oleh Hasibuan memang seringkah dipergunakan oleh seorang pemimpin dalam memotivasi bawahannya, yakni dengan memberikan hadiah kepada bawahan yang berprestasi baik, serta hukuman kepada bawahan yang prestasi kerjanya rendah. 
Dalam kegiatan pemberian motivasi oleh seorang pemimpin terhadap bawahan, terdapat azas-azas pemberian motivasi melalui asas mengikutsertakan, artinya mengajak bawahan untuk ikut berpartisipasi dan memberikan kesempatan kepada mereka mengajukan pendapat, rekomendasi dalam proses pengambilan keputusan. Azas komunikasi, artinya menginformasikan secara jelas tentang tujuan yang ingin dicapai, cara-cara mengerjakannya dan kendala-kendala yang dihadapi. Azas pengakuan., artinya memberikan penghargaan., pujian dan pengakuan yang tepat serta wajar kepada bawahan atas prestasi kerja yang dicapainya. Azas wewenang yang didelegasikan, artinya memberikan kewenangan dan kepercayaan diri kepada bawahan, bahwa dengan kemampuan dan kreativitasnya ia mampu mengerjakan tugas-tugas tertentu dengan baik.Azas adil dan layak, artinya alat dan jenis motivasi yang diberikan harus berdasarkan atas azas-azas keadilan dan kelayakan-kelayakan terhadap semua karyawan.

Memotivasi seseorang lebih mudah diucapkan daripada dilaksanakan, karena tiap orang memiliki kebutuhan yang berbeda-beda. Oleh karena itu, setelah membicarakan mekanisme atau proses motivasi, maka perbincangan akan mengarah pada persoalan hal-hal yang dibutuhkan dan diinginkan orangorang. Ada beberapa teknik memotivasi kerja pegawai yaitu teknik pemenuhan kebutuhan pegawai dan teknik komunikasi persuasif. Kedua teknik tersebut dijelaskan sebagai kebutuhan fisiologis, yaitu kebutuhan makan, minum, perlindungan fisik, bernapas, dan seksual. Kebutuhan ini merupakan kebutuhan yang paling mendasar. Dalam hubungan dengan kebutuhan ini pemimpin perlu memberikan gaji yang layak kepada pegawai. Kebutuhan rasa aman, yaitu kebutuhan perlindungan dari ancaman, bahaya, dan lingkungan kerja. Dalam hubungan dengan kebutuhan ini pemimpin perlu memberikan tunjangan kesehatan, asuransi kecelakaan, perumahan, dan dana pensiun. Kebutuhan sosial atau rasa memiliki, yaitu kebutuhan untuk diterima dalam kelompok unit kerja, berafiliasi, berinteraksi, serta rasa dicintai dan mencintai. Dalam hubungan dengan kebutuhan ini, pemimpin perlu menerima eksistensi atau keberadaan pegawai sebagai anggota kelompok kerja, melakukan interaksi kerja yang baik, dan hubungan kerja yang harmonis.

Organisasi dapat dianggap sebagai sebuah kerangka yang merupakan titik pusat sekitarnya, apakah para pegawai yang ada di kantor ini dapat menghubungkan usaha usaha mereka dengan baik. Selain itu dapat dibayangkan apabila ditemui struktur organisasi yang kurang teratur, maka efektifitas kerja yang diharapkan akan jauh dari kenyataan. $\mathrm{Hal}$ ini adalah logis sebab dengan tidak adanya hubungan kerjasama yang baik dalam arti fungsi staf akan menjadikan pengkaburan dalam batas wewenang dan tanggung jawab pelaksanaan tugas. Ketidakjelasan batas wewenang dan tanggung jawab seseorang mengakibatkan ia merasa tidak terikat dengan berbagai macam aturan aturan. Proses pengorganisasian menyangkut bagaimana kegiatan organisasi dialokasikan serta pembagian pekerjaan di antara anggotanya agar tujuan organisasi dapat tercapai dengan efisien. Organisasi dalam arti sekelompok orang yang bekerja sama untuk mencapai suatu tujuan tertentu. Pada dasarnya organisasi merupakan suatu kerjasama dalam suatu tim yang diartikan tidak dapat terpisah dengan kegiatan lainnya. Proses kerjasama tersebut dapat digabungkan dalam suatu pekerjaan yang akan menjadi suatu kelompok. Selain itu organisasi kerja yang bergerak dibidang perhubungan lalulintas dapat melaksanakan visi dan misinya sesuai ketentuanm yang berlaku sehingga proses penggabungan pekerjaan pada individu atau kelompok-kelompok harus melakukan dengan bakat yang diperlukan untuk melakukan tugas-tugas sedemikian rupa memberikan saluran terbaik untuk pemakaian yang efisien, sistematis, positif, dan terkoordinasikan dari usaha yang tersedia.

Oleh karena itu, struktur organisasi berkaitan dengan pembagian uraian tugas dan hubungan yang bersifat relatif tetap dalam organisasi, bagaimana pekerjaan-pekerjaan dalam organisasi dirancang, bagaimana pekerjaan itu diatur dalam bagan organisasi, struktur organisasi berpengaruh besar terhadap perilaku individu atau orang-orang dalam organisasi serta efektivitas dalam organisasi tersebut. Dengan demikian, organisasi selain membawa pengaruh pada perilaku individu dan kelompok dalam organisasi juga berpengaruh dan dipengaruhi oleh lingkungan organisasi itu sendiri, dalam mencapai tujuan organisasi. Pelaksanaan pekerjaan atau kegiatan dalam organisasi sudah barang tentu yang paling penting dalam fungsi manajemen karena merupakan pengupayaan berbagai jenis tindakan itu sendiri, agar semua anggota kelompok mulai dari tingkat teratas sampai terbawah berusaha mencapai sasaran organisasi sesuai rencana yang telah ditetapkan semula dengan cara terbaik dan benar.

Dengan demikian, struktur organisasi merupakan sistem pengelompokan pekerjaan yang ditata dalam suatu struktur agar organisasi tersebut dapat digerakan secara maksimal dalam suatu jalinan kerja yang efektif dan efisien. Selain itu dalam struktur adanya kerjasama, merupakan unsur yang terpenting dalam organisasi, karena dengan 
adanya hubungan yang baik/kerjasama yang baik maka keberhasilan pencapaian tujuan organisasi akan lebih cepat. Kerjasama ini bukan hanya terjadi antara individu atau antara unit/bagian saja melainkan adanya kerjasama dengan instansi terkait lainnya. Kemampuan administratif pegawai, sebagai bentuk dari kemampuan sumber daya manusia merupakan unsur penentu dalam keberhasilan organisasi dalam produktivitas kerja. Sumber daya manusia dalam hal ini adalah pegawai, perlu terus dikembangkan baik dari segi pendidikan formalnya maupun pendidikan jenjang kariernya. Dengan kualitas pegawai yang semakin meningkat diharapkan adanya perubahan kerja, etos kerja pegawai meningkat sehingga timbul rasa memiliki organisasi dan tercipta rasa kepuasan baik individu sendiri maupun keseluruhan organisasi.

Perencanaan Program Kerja memegang peranan dalam memulai sesuatu kegiatan atau melakukan suatu pekerjaan. Perencanaan yang baik merupakan perencanaan yang melibatkan baik unsur-unsur pimpinan maupun bawahan dalam menentukan kebijakan manajemen organisasi. Bukan hanya keterlibatan bawahan saja melainkan dalam menyusun suatu rencana program kerja memperhatikan faktor-faktor baik internal maupun eksternal dalam membahas suatu perencanaan yang sifatnya strategik. Kepuasan kerja merupakan suatu kondisi yang dirasakan oleh seluruh anggota organisasi yang mampu memberikan kenyamanan dan motivasi bagi peningkatan kinerja organisasi secara keseluruhan untuk mencapai efektifitas organisasi.

\section{KESIMPULAN DAN SARAN}

Koordinasi vertikal yang dalam artian bahwa adanya penyatuan kegiatan, pengarahan yang dilakukan oleh atasan terhadap kegiatan unitunit, kesatuan-kesatuan kerja yang ada di bawah wewenang dan tanggung jawabnya. Selanjut atasan mengkoordinasi semua pegawai yang ada di bawah tanggung jawabnya secara langsung. Selain itu

\section{DAFTAR PUSTAKA}

Achmadi, A.1994. Psikologi Sosial. Jakarta: PT Rinneka Cipta.

Badudu, J.S. dan Zain Sm. 1996. Kamus Umum Bahasa Indonesia. Jakarta: Pustaka Sinar Harapan

Departemen Pendidikan Nasional. 2001. Kamus Besar Bahasa Indonesia. Edisi Ketiga. Jakarta: Balai Pustaka.

Faisal, S. 1990. Peneliatian Kualitatif. Malang: Yayasan Asih Asah Asuh. koordinasi vertikal ini secara relatif mudah dilakukan, karena atasan dapat memberikan sanksi kepada pegawai yang sulit diatur. Kemudian koordinasi horizontal pimpinan mengkoordinasikan kegiatan-kegiatan yang ada dikantor dan pengarahan yang dilakukan terhadap kegiatan organisasi. Selain itu koordinasi horizontal ini dapat menciptakan disiplin kerja antara unit yang satu dengan unit yang lain secara internal maupun eksternal pada unit-unit yang sama tugasnya. Koordinasi antar badan beserta unit-unit yang fungsinya berbeda, tetapi instansi yang satu dengan yang lain saling bergantung atau mempunyai kaitan setara. Pelaksanaan koordinasi kerja pimpinan juga telah dilakukan melalui peranan pimpinan yang dominan dalam organisasi. Peranan yang dominan dapat mempengaruhi moral kepuasan kerja, kualitas kerja dan terutama tingkat prestasi suatu organisasi. Selain itu motivasi yang diberikan pemimpin berupa pandangan dan dorongan dalam bentuk hadiah kepada pegawai yang berprestasi baik, dengan adanya perhatian dan dorongan. Setiap orang termotivasi untuk berperilaku dalam cara tertentu yang dirasakan mengarah kepada perolehan ganjaran. Selain itu teknik memotivasi kerja yang di berikan pimpinan melalui teknik pemenuhan kebutuhan pegawai dan teknik komunikasi yang bersifat persuasif. Struktur ini dapat dianggap sebagai sebuah kerangka yang dapat memperjelas menghubungkan kerja. Dinas Perhubungan Komunikasi dan Informatika Kabupaten Melawi agar memperhatikan dan meningkatkan koordinasi Vertikal dan horizontal kepada badan atau lembaga terkait melalui kepemimpinan mengayomi dan melayani, sehingga tujuan organisasi dapat berjalan sesuai ketentuan yang berlaku. Koordinasi kerja pimpinan perlu ditingkatkan secara baik antar instansi yang terkait melalui pendekatan motivasi dan teknik-teknik kepemimpinan, serta pembagian tugas semakin baik dan jelas dalam menjalankan roda organisasi yang dapat melayanani kepentingan bersama.

Gito Sudarmo, I. 1999. Perilaku Keorganisasian. Edisi Pertama. Jakarta: BPFEE.

Gibson, 1997. Organisasi, Perilaku, Struktur, proses. Jakarta: Airlangga

Handoko, T. Hani. 2003. Manajemen. Edisi Kedua. Cetakan Kedelapanbelas. Yogyakarta: BPFE-Yogyakarta

Hasibuan, M. 2002. Manajemen Sumber Daya Manusia. Jakarta: Bumi Aksara. 
2007. Manajemen: Dasar, Pengertian, dan Masalah. Cetakan Keenam. Jakarta: Bumi Aksara.

Ismani dan Suyadi. 2000. Metode Penelitian. Malang: BPP FIA Unibraw.

Manullang, M. 2005. Dasar-Dasar Manajemen. Yogyakarta: Gajah Mada University Press.

Mangkunegara, A. A. Anwar Prabu. 2001. Manajemen Sumber Daya Perusahaan. Bandung : Remaja Rosdakarya.

Nawawi, H. 2001. Metode Penelitian di Bidang Sosial. Yogyakarta : Gajahmada University Press.

Saydam Gouzali 2000. Manajemen Sumber Daya Manusia. Penerbit Djambatan.

Siagian, SP. 1983. Organisasi, Kepemimpinan dan Perilaku Administrasi. Jakarta: XIV Sapdodadi.

Singarimbun dan Effendi , 1989. Metode Penelitian Survey. Yakarta: LP3ES

Simanjuntak B, dan Pasaribu L. 1986. Sosiologi Pembangunan. Tarsito: Bandung.

Suryabrata.S. 2000. Metodologi Penelitian. Jakarta : PT.Raja Grafindo Persada.
Sutarto. 1995. Dasar-Dasar Organisasi. Yogyakarta: Gajahmada University Press

Sastro Hadiwiryo.S.2002. Manajemen Tenaga Kerja Indonesia. Jakarta : PT. Bumi Aksara.

Soekanto, S. 2002. Hukum Adat di Indonesia. Jakarta: PT. Grapindo Persada.

Tim Penyusun Kamus Bahasa, Pusat Pembinaan dan Pengembangan Bahasa. 1989.

Kamus Bahasa Indonesia. Jakarta: Balai Pustaka

Toha, M. 2001. Perilaku Organisasi Konsep Dasar Aplikasinya. Jakarta: CV. Rajawali

Winardi, J. 2000. Motivasi Dan Pemotivasian Dalam Manajemen. Jakarta : PT. Raja Grafindo Persada.

Wahjosumidjo. 1984. Kepemimpinan dan Motivasi. Jakarta : Ghalia Indonesia.

\section{Peraturan Perundangan:}

Undang-Undang Nomor 5 Tahun 2014 Tentang Pokok-pokok Kepegawaian sebagaimana telah diubah dengan Undang- Undang Nomor. 43 Tahun 1999

Undang-Undang RI Nomor 32 Tahun 2004 Tentang Pemerintahan Daerah. 